\title{
An update of the geographical distribution of Pleurodema marmoratum (Duméril \& Bibron, 1840) in the Chilean Altiplano
}

\author{
Pablo Fibla ${ }^{1}$, Franco Cruz-Jofré1,2, Michel Sallaberry ${ }^{3}$, Marco A. Méndez ${ }^{1}$, Luis Pastenes ${ }^{4}$ \\ 1 Laboratorio de Genética y Evolución, Departamento de Ciencias Ecológicas, Universidad de Chile. Las Palmeras \#3425, Santiago, Chile \\ 2 Escuela de Medicina Veterinaria, Facultad de Recursos Naturales y Medicina Veterinaria, Universidad Santo Tomás. Los Limonares \#190, \\ Viña del Mar, Chile \\ 3 Laboratorio de Zoología de Vertebrados, Departamento de Ciencias Ecológicas, Universidad de Chile. Las Palmeras \#3425, Santiago, Chile \\ 4 Laboratorio de Genética y Adaptación a Ambientes Extremos, Departamento de Biología y Química, Facultad de Ciencias Básicas, \\ Universidad Católica del Maule. Av. San Miguel \#3605, Talca, Chile \\ http://zoobank.org/19910C4D-FD83-438F-AD8F-DA3C440B8748 \\ Corresponding author: Luis Pastenes (lpastenes@ucm.cl)
}

Academic editor: Günter Gollmann • Received 3 December 2019 • Accepted 4 January 2020 • Published 4 February 2020

\begin{abstract}
This study summarizes new and historical records of one of the least known anuran species from the Chilean Altiplano, Pleurodema marmoratum (Duméril \& Bibron, 1840). The discovery of a new population in the Altiplano of the Región de Antofagasta extends the known distribution of this species in Chile approximately $100 \mathrm{~km}$ south.
\end{abstract}

\section{Key Words}

Andes, Anura, highlands, Leptodactylidae

Pleurodema marmoratum (Duméril \& Bibron, 1840) is a native anuran of the South American highlands, which is distributed across Peru, Bolivia, Argentina and Chile in an altitudinal range from 3,000 to 5,200 meters above sea level (Duellman and Veloso 1977; Seimon et al. 2007). Although this species is widely distributed in the center of the Altiplano basin, there are few reports of populations located at the margin of its distribution (e.g., in Chile and Argentina). In Chile, the known geographical distribution of $P$. marmoratum is disjunctive due to the fragmented nature of the habitat it occupies (i.e., high Andean or Altiplano wetlands) and to the fact that its populations are separated by long distance. This species was first recorded in Chile by Cei (1958), who identified two specimens collected in the town of Caquena, located in northern Chile (Región de Arica y Parinacota). Subsequently, this species was reported in the surround- ing area of Putre and Parinacota in the Lauca National Park (Veloso et al. 1982), not far from the record by Cei (1958). Most recently, the distribution of $P$. marmoratum extended $145 \mathrm{~km}$ south, up to the Quebe wetland (Región de Tarapacá), including the southern area of the Lauca National Park as well (Sallaberry et al. 2007). Except for two poorly documented records further south (Bonacic et al. 2015), no new reports were published on the presence of this species in Chile. In fact, P. marmoratum has been categorized as "Endangered" and "Rare" inside Chilean territory (Comisión Nacional del Medio Ambiente 2007), since its populations occupy a small geographic area and are restricted to a very specific habitat. Nevertheless, the designation of this conservation status could be a consequence of the scarcity of herpetological explorations in the Andean territory/region of northern Chile, just as it has been described for other groups of anurans distributed 


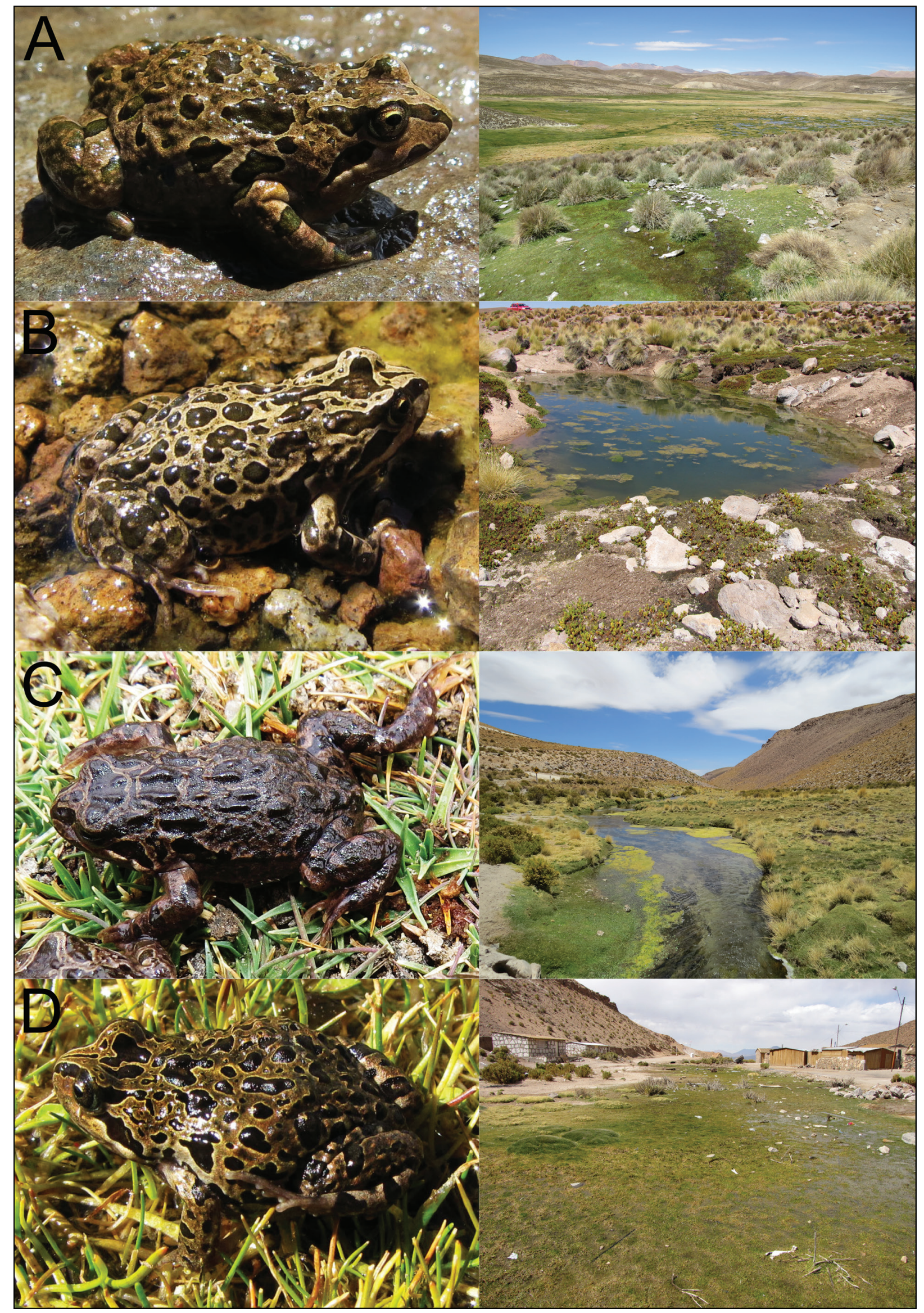

Figure 1. Specimens of Pleurodema marmoratum and their respective habitats. The localities sampled are as follows: A) Colpa, B) Ocacucho, C) Piga, and D) Coska. 


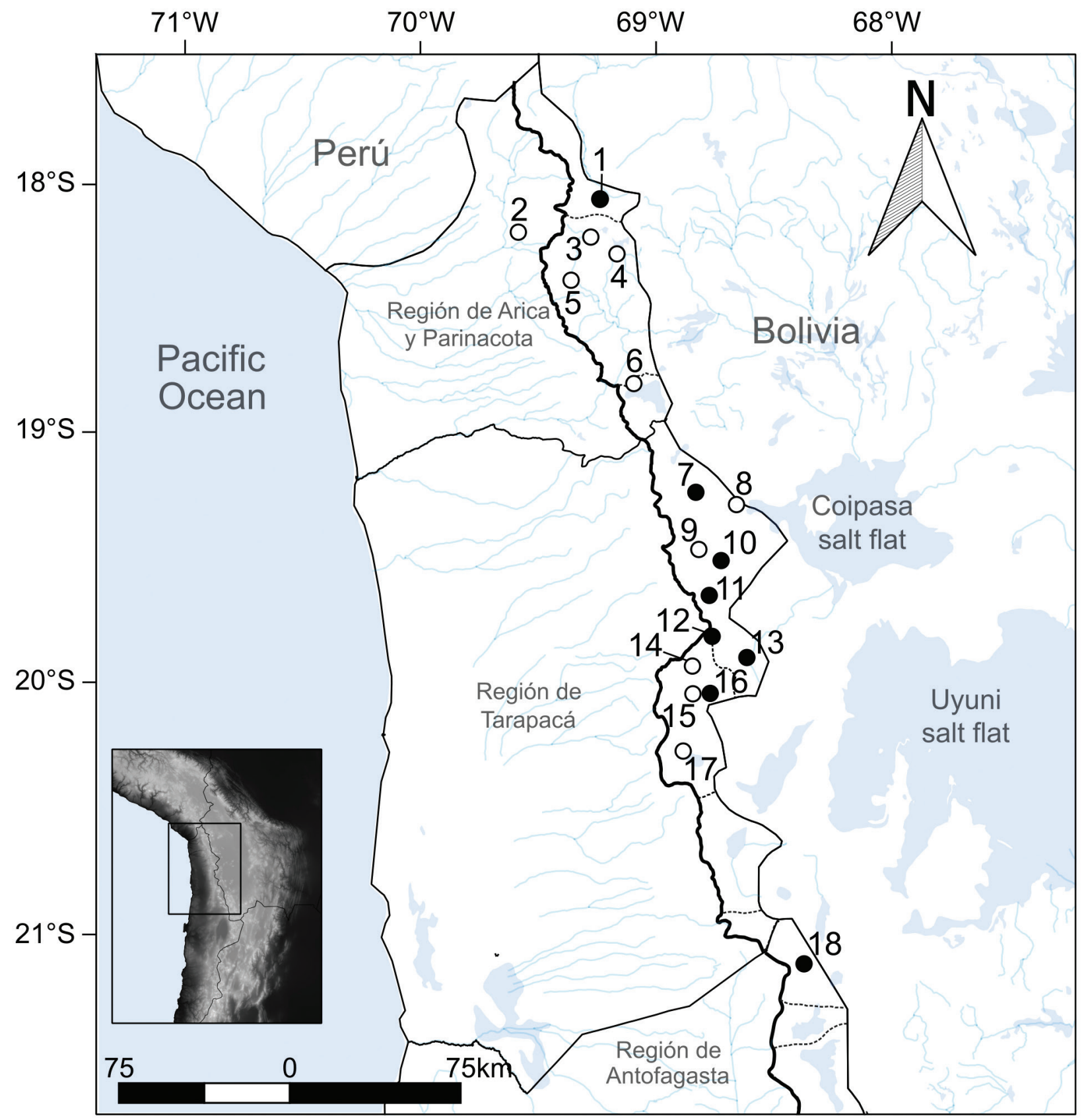

Figure 2. Geographical distribution of Pleurodema marmoratum populations from the Chilean Altiplano. Solid lines: regional limits; solid thick line: Altiplano basin limit; dotted lines: Altiplano drainage sub-basin limits; empty circles: historical records; filled circles: new records. The numbers on the circles are referred to in Table 1.

in that area, such as the case of the genus Telmatobius (see Sáez et al. 2014). Therefore, this work synthetizes the historical records and contributes new findings within the known distribution of Pleurodema marmoratum in Chilean territory, including a record that extends the distribution to the Altiplano of the Región de Antofagasta.

The findings documented in this work correspond to records made between 2014 and 2019, during field campaigns carried out in the high Andean area of the Región de Arica y Parinacota, Región de Tarapacá and Región de Antofagasta, Chile. The specimens of P. marmora- tum reported here were found under rocks located at the margins of the streams and wetlands prospected in the Altiplano (Figure 1), and were identified based on the diagnosis provided by Veloso et al. (1982). The specimens found were neither collected nor sampled.

The geographical distribution of $P$. marmoratum in the Chilean Altiplano is summarized in Figure 2 and Table 1. Previous records of this species are located between the Caquena (Región de Arica y Parinacota) and Quebe (Región de Tarapacá) wetlands. Moreover, we found an old record belonging to a specimen collected in the Huasco 
Table 1. Geographical coordinates from the Pleurodema marmoratum records in the Chilean Altiplano. ${ }^{1}$ Región de Arica y Parinacota; ${ }^{2}$ Región de Tarapacá; ${ }^{3}$ Región de Antofagasta. ${ }^{*}$ No reported geographical coordinates in the reference.

\begin{tabular}{|c|c|c|c|c|}
\hline Map & Locality & Geographical coordinates & Elevation (m) & Reference \\
\hline 1 & Colpa-Colpita ${ }^{1}$ & $18^{\circ} 03^{\prime} 33.27^{\prime \prime S}, 69^{\circ} 13^{\prime} 57.74^{\prime \prime} \mathrm{W}$ & 4,361 & This work \\
\hline 2 & Putre $^{1}$ & $18^{\circ} 12^{\prime} \mathrm{S}, 69^{\circ} 35^{\prime} \mathrm{W}$ & 3,530 & Veloso et al. 1982 \\
\hline 3 & Parinacota $^{1}$ & $18^{\circ} 11^{\prime} \mathrm{S}, 69^{\circ} 17^{\prime} \mathrm{W}$ & 4,300 & Veloso et al. 1982 \\
\hline 4 & Chungará $^{1}$ & $18^{\circ} 15^{\prime} \mathrm{S}, 69^{\circ} 10^{\prime} \mathrm{W}$ & 4,600 & Veloso et al. 1982 \\
\hline 5 & Lauca sur ${ }^{1}$ & $18^{\circ} 22^{\prime} 36.92^{\prime \prime} \mathrm{S}, 69^{\circ} 21^{\prime} 06.61^{\prime \prime} \mathrm{W}$ & 4,232 & Sallaberry et al. 2007 \\
\hline 6 & Surire $^{1}$ & - & - & S. Flores and E. Gutierrez, pers. comm. \\
\hline 7 & Enquelga $^{2}$ & $19^{\circ} 13^{\prime} 44.30^{\prime \prime} \mathrm{S}, 68^{\circ} 49^{\prime} 18.70^{\prime \prime} \mathrm{W}$ & 3,951 & This work \\
\hline 8 & Isluga $^{2}$ & $19^{\circ} 16^{\prime} 46.00^{\prime \prime} \mathrm{S}, 68^{\circ} 38^{\prime} 48.00^{\prime \prime} \mathrm{W}$ & 3,730 & Nuñez and Gálvez 2015 \\
\hline 9 & Quebe $^{2}$ & $19^{\circ} 27^{\prime} 28.68^{\prime \prime} \mathrm{S}, 68^{\circ} 48^{\prime} 33.46^{\prime \prime} \mathrm{W}$ & 3,958 & Sallaberry et al. 2007 \\
\hline 10 & Toroni $^{2}$ & $19^{\circ} 30^{\prime} 08.90^{\prime \prime} \mathrm{S}, 68^{\circ} 42^{\prime} 52.80^{\prime \prime} \mathrm{W}$ & 3,838 & This work \\
\hline 11 & Cotaculco $^{2}$ & $19^{\circ} 38^{\prime} 30.47^{\prime \prime} \mathrm{S}, 68^{\circ} 45^{\prime} 53.90^{\prime \prime} \mathrm{W}$ & 4,269 & This work \\
\hline 12 & Río Ocacucho² & $19^{\circ} 48^{\prime} 45.20^{\prime \prime} \mathrm{S}, 68^{\circ} 45^{\prime} 57.00^{\prime \prime} \mathrm{W}$ & 4,653 & This work \\
\hline 13 & Cancosa $a^{2}$ & $19^{\circ} 53^{\prime} 23.53^{\prime \prime S}, 68^{\circ} 36^{\prime} 18.92^{\prime \prime W}$ & 3,913 & This work \\
\hline 14 & Lagunillas $^{2}$ & - & - & Bonacic et al. $2015^{*}$ \\
\hline 15 & Collacagua $^{2}$ & - & - & Bonacic et al. $2015^{*}$ \\
\hline 16 & Piga $^{2}$ & $20^{\circ} 02^{\prime} 23.94^{\prime \prime} \mathrm{S}, 68^{\circ} 45^{\prime} 39.31^{\prime \prime W}$ & 4,225 & This work \\
\hline 17 & Huasco $^{2}$ & - & - & Moreno et al. $2001^{*}$ \\
\hline 18 & Coska $^{3}$ & $21^{\circ} 06^{\prime} 55.79^{\prime \prime} \mathrm{S}, 68^{\circ} 21^{\prime} 50.73^{\prime \prime} \mathrm{W}$ & 4,047 & This work \\
\hline
\end{tabular}

salt flat, Región de Tarapacá, located south of the Quebe wetland (Moreno et al. 2001); however, the coordinates of the collection site were not provided. The new records of P. marmoratum reported here include the locality of Colpa in the Región de Arica y Parinacota, a number of localities in the Región de Tarapacá (Enquelga, Toroni, Cotaculco, Ocacucho, Cancosa and Piga), and the town of Coska, in the Altiplano of the Región de Antofagasta, all located approximately between 3,500 and 4,600 meters of altitude. The record of Coska extends the known distribution for this species in Chile to approximately $100 \mathrm{~km}$ south. On the other hand, it was not possible to locate the populations of P. marmoratum described by Veloso et al. (1982) for the Lauca National Park (Región de Arica y Parinacota), although other anuran species that were registered in that work have been observed again in nearby areas (e.g., Telmatobius peruvianus in Putre; Sáez et al. 2014). In this region, specimens of $P$. marmoratum were recorded in the town of Colpa, near Parinacota, at the northern end of its distribution in Chile. Colpa is a wetland near Caquena (separated by no more than $3 \mathrm{~km}$ ). Taking into account the geographical proximity of both localities and the fact that they are connected by a branch of the Caquena river, we suggest that our record could correspond to the population of P. marmoratum described by Cei (1958) for the Altiplano of the Región de Arica y Parinacota.

Given that most of the new findings were made in the Región de Tarapacá (Isluga National Park), this geographical location could correspond to the center of the distribution of P. marmoratum in Chile. The populations of this species in the Región de Tarapacá inhabit wetlands located west of the Coipasa and Uyuni salt flats and are separated from the populations registered in the Lauca National Park by a long distance (approximately $140 \mathrm{~km}$ ). However, a recent record for this species in the Surire salt flat (S. Flores and E. Gutierrez, CONAF; personal communication), suggests the presence of other populations between those of Región de Tarapacá and Lauca National Park. Furthermore, the Coska population, corresponding to the new southern limit for the distribution of P. marmoratum in Chile, illustrates the fragmented nature of the distribution of this species. This population is widely separated from the rest of the populations present in Chile and is apparently not associated with a permanent wetland (i.e., wetland fed by melting ice). In any case, it is not surprising that the distribution of $P$. marmoratum would extend to the Región de Antofagasta in Chile, since records in Argentine territory extend to the Provincia de Jujuy (Ferraro et al. 2009).

The detection of only a few specimens in each of the prospected localities suggests that the population densities of this species are low, as previously described by the IUCN Amphibian Specialist Group (2014). The two records made in the Colpa wetland are separated by approximately $2.5 \mathrm{~km}$, suggesting that $P$. marmoratum populations may cover wide areas. On the other hand, the evidence presented here could generate a change in the status of this species for Chile, since it has a wide geographical range with presence in several locations within this country, although its populations are highly fragmented.

Finally, due to the wide geographical distribution of this species and its high degree of fragmentation, it is feasible to infer that there is more than one lineage of $P$. marmoratum in Chile. Previously, Vellard (1960) recognized different subspecies of $P$. marmoratum, but Duellman and Veloso (1977) suggested that these subspecies would not be valid, pointing out that $P$. marmoratum populations are highly polymorphic, which is a hypothesis that must be reevaluated by integrative studies that cover the entire distribution of the species. 


\section{Acknowledgements}

Franco Cruz thanks CONICYT-PCHA/Doctorado Nacional/2015-21150821. Luis Pastenes thanks Grant FONDECYT-CONICYT 3140483.

\section{References}

Bonacic C, Riquelme-Valeria P, Leichtle J, Sallaberry-Pincheira N (2015) Guía de campo: Anfibios y Reptiles de la Región de Tarapacá. Serie Fauna Australis, Facultad de Agronomía e Ingeniería Forestal, Pontificia Universidad Católica de Chile, Santiago, 70 pp.

Cei JM (1958) Sobre la presencia de Pleurodema marmorata (D. \& B.) en territorio chileno. Investigaciones Zoológicas Chilenas 4: 32. http://www.bibliotecanacionaldigital.gob.cl/visor/BND:67272

Comisión Nacional del Medio Ambiente (2007) Propuesta Definitiva para el Segundo Período de Clasificación de Especies Silvestres, Chile. https://clasificacionespecies.mma.gob.cl/wp-content/uploads/2019/10/ Acuerdo_362Aprueba2dopeCE.pdf

Duellman WE, Veloso A (1977) Phylogeny of Pleurodema (Anura: Leptodactylidae): a biogeographic model. Occasional Papers of the $\mathrm{Mu}$ seum of Natural History, the University of Kansas 64: 1-46.

Ferraro DP, Casagranda MD (2009) Geographic distribution of the genus Pleurodema in Argentina (Anura: Leiuperidae). Zootaxa 2024: 33-55. https:/www.researchgate.net/profile/ Daiana_Ferraro/publication/261796225_Geographic_distribution_of_the_genus_Pleurodema_in_Argentina_Anura_Leiuperidae/links/0c9605357fa30223af000000/Geographic-distribution-of-the-genus-Pleurodema-in-Argentina-Anura-Leiuperidae.pdf
IUCN SSC Amphibian Specialist Group (2014) Pleurodema marmoratum. The IUCN Red List of Threatened Species 2014: e. T57289A43783661. https://doi.org/10.2305/IUCN.UK.2014-1.RLTS. T57289A43783661.en

Moreno R, Moreno J, Torres-Pérez F, Ortiz JC, Breskovic A (2001) Herpetological catalogue of Museo del Mar of Arturo Prat University, Iquique, Chile. Gayana 65(2): 149-153. https://doi.org/10.4067/ S0717-65382001000200006

Sáez PA, Fibla P, Correa C, Sallaberry M, Salinas H, Veloso A, Mella J, Iturra P, Méndez MA (2014) A new endemic lineage of the Andean frog genus Telmatobius (Anura, Telmatobiidae) from the western slopes of the central Andes. Zoological Journal of the Linnean Society 171(4): 769-782. https://doi.org/10.1111/zoj.12152

Sallaberry M, Pastenes L, Correa C, Méndez MA (2007) Pleurodema marmorata (Andean Four-eyed Frog). Herpetological Review 38(3): 349. https://ssarherps.org/herpetological-review-pdfs/

Seimon TA, Seimon A, Daszak P, Halloy SRP, Schloegel LM, Aguilar CA, Sowell P, Hyatt AD, Konecky B, Simmons JE (2007) Upward range extension of Andean anurans and chytridiomycosis to extreme elevations in response to tropical deglaciation. Global Change Biology 13(1): 288-299. https://doi.org/10.1111/j.1365-2486.2006.01278.x

Vellard J (1960) El género Pleurodema en los Andes Peruanos. Memorias del Museo de Historia Natural "Javier Prado" 10: 1-12. https://museohn.unmsm.edu.pe/docs/Memorias/Memoria\%20 N\%C2\%B0\%2010.pdf

Veloso A, Sallaberry M, Navarro J, Iturra P, Valencia J, Penna M, Díaz N (1982) Contribución sistemática al conocimiento de la herpetofauna del extremo norte de Chile. In: Veloso A, Bustos E (Eds) La Vegetación y vertebrados ectotérmicos del transecto Arica-Lago Chungará. ROSTLAC, Montevideo, 135-268. 